\title{
AUTOCUIDADO APOIADO, PROTEÇÃO COLETIVA E INDIVIDUAL, EM ÉPOCA DE CRISE HUMANITÁRIA
}

Willians Cassiano Longen

DOI: http://dx.doi.org/10.18616/intcov28

É no contexto de uma pandemia destas, que fica mais clara a noção de que somos mortais, dentro da nossa limitada condição existencial humana. De forma dolorosa, temos que aprender muita coisa em curto espaço de tempo, tentando, por exemplo, "não representarmos espécie de lenha altamente e potencialmente inflamável, em uma floresta que se encontra em chamas". Áreas como a saúde e a segurança, nas diversas atividades humanas de vida e trabalho, passam a ser melhor enxergadas e a ser devidamente valorizadas de maneira inegociável. Afinal, passar por uma pandemia externaliza as tranças de aço que qualquer coração mais frio possa ter ao redor de si.

O caminho mais curto e tendencioso sempre tem sido de estarmos facilmente perdidos de nós mesmos e da noção de coletividade. O senso de proteção coletiva vem à tona com uma mão bastante pesada e cobrando uma percepção que, infelizmente, não está presente na maioria da nossa sociedade. Como já havia expressado Aristóteles "O sábio aspira não ao prazer mas à ausência de dor".

Nesse contexto, se eu tenho dificuldades de autocuidado e de exercitar também autocuidado individual, como cuidarei do outro? Como os coletivos irão se comportar? A virtude olha com certo desprezo a agitação do povo que, no seu ímpeto autodestrutivo, filtra sua consciência e essência responsável, pautada por valores e crenças que vieram durante muitos anos sendo massageados por uma percepção ilusória de inviolabilidade.

Em paralelo, vem à tona como temos ignorado o custo ambiental das novas formas de relacionamentos socioeconômicos e ambientais globais. $\mathrm{O}$ aumento e a aceleração da destruição do meio ambiente natural no nosso 
planeta parecem tão graves quanto os efeitos socioeconômicos, considerando que numa perspectiva sistêmica e global, fazem parte do contexto. Será que as escolhas que as práticas econômicas e de vida que temos eleito são em certa dimensão insustentáveis? Já destacava Capra (2002), na sua obra As conexões ocultas: ciência para uma vida sustentável, que a expansão desordenada de nosso planeta finito nos condiciona à catástrofe.

Todos nossos sentidos se aguçam e qualquer frase de música toma uma dimensão diferente e não há necessidade de estender a reflexão sobre os trechos das composições para que rapidamente suas conexões com a pandemia ganhem sentido... "é preciso saber viver", "mother, you and me", "help", "devia ter amado mais" e tantas e tantas outras.

A prudência humana é chamada à tona e um senso coletivo maior, nesse momento, é exercitado, mesmo que forjado a ferro e fogo, mas que deve servir para que, logo ali em seguida, não voltemos a caminhar com percepções limitadas acerca do que realmente importa e que conta com incalculável valor.

\section{REFERÊNCIAS}

CAPRA, Fritjof. As conexões ocultas: ciência para uma vida sustentável. São Paulo: Cultrix, 2002. 